\title{
Evaluation of Demographic and Clinicopathological Characteristics of Osteosarcoma Patients
}

\section{Osteosarkom Tanılı Hastaların Demografik ve Klinikopatolojik Özelliklerinin Değerlendirilmesi}

\author{
Recep Öztürk ${ }^{1}$ Bülent İnce², Yaman Karakoç¹, Ali Ekber Yapar ${ }^{1}$, Yusuf İkbal Erdoğdu¹, Bedii Şafak \\ Güngör ${ }^{1}$ \\ ${ }^{1}$ Dr. Abdurrahman Yurtaslan Ankara Onkoloji Eğitim Ve Araştırma Hastanesi, Ortopedi Ve Travmatoloji, \\ Ankara \\ ${ }^{2}$ Etimed Hastanesi, Ankara
}

Dergiye Ulaşma Tarihi:22.05.2019 Dergiye Kabul Tarihi:26.06.2019 Doi: 10.5505/aot.2019.60234

\section{ÖZET}

GİRIŞ ve AMAÇ: Hastanemiz Ortopedi ve Travmatoloji Kliniğinde Ocak 2002 - Ocak 2015 tarihleri arasında osteosarkom tanısı almış ve cerrahi tedavisi uygulanmış olan 122 hastanın retrospektif analizi amaçlandı.

YÖNTEM ve GEREÇLER: 81'i erkek (\%66.3), 41'i kadın (\%33.7), , toplam 122 hasta çalışmaya dahil edildi.Hastalara ilişkin tüm veriler retrospektif olarak eksiksiz şekilde değerlendirildi, hastaların \%95.9'u opere edildi, bu hastalardan \%72.7'sinde ekstremite koruyucu cerrahi, \%27.3'ünde amputasyon uygulandi. BULGULAR: Ortalama yaş 23.9 (7-82 yaş arası) idi. Hastaların \%50'si 11-20 yaş arası genç gruptu, $\% 66,3$ 'ü diz çevresi (\%50,8'i femur distal ve \%15.5'i tibia proksimal) yerleşimliydi. Tanı anında vakaların \%59'unun Enneking Evre 2B olduğu görüldü. En sık tümör tipi konvansiyonel osteosarkomdu.

TARTIŞMA ve SONUÇ: Hastanemizde tanı almış osteosarkom vakaları incelendiğinde, tümör dağglımı ve özelliklerinin dünya literatürü ve Türkiye'deki diğer lokal hastane verilerine benzer şekilde olduğu saptanmıştır.

Anahtar Kelimeler: osteosarkom, cerrahi, tedavi, malign, kemik tümörü.

\section{ABSTRACT}

INTRODUCTION: It is aimed that a retrospective analysis of 122 patients who were diagnosed with osteosarcoma and underwent surgical treatment between January 2002 and January 2015 at the Orthopedics and Traumatology Clinic of our Hospital.

METHODS: Total of 122 patients (81 males, 41 females) were included in the study. All data were retrospectively and completely evaluated, $95,9 \%$ of the patients were operated, $72,7 \%$ of these patients, had limb salvage surgery and $27,3 \%$ had amputation.

RESULTS: The mean age was 23.9 years (range 7-82 years), 50\% of the patients were between 11 and 20 years of age and $66.3 \%$ of them were located in the knee $(50.8 \%$ distal femur and $15.5 \%$ proximal tibia). At the time of diagnosis, 59\% of cases were found to be Enneking Stage 2B. The most common tumor type was conventional osteosarcoma.

DISCUSSION: When we examined the cases of osteosarcoma which diagnosed in our hospital, the distribution and features of tumor was similar to other cases that is in other hospitals in our country and the world literature.

Keywords: osteosarcoma, surgical, treatment, malignant, bone tumor.

\section{INTRODUCTION}

Osteosarcoma is a malignant bone tumor derived from primitive mesenchymal cells and consisting of malignant cells producing bone and osteoid matrix $(1,2)$. It is the most common malignant bone tumor in children and young adults $(3,4)$.
The most common age range is the second decade of life and the most common sites are metaphyseal localization of long bones such as distal femur, proximal tibia and proximal humerus $(2,5,6)$.

The standard treatment for osteosarcoma was limb amputation in the past because of the rapid and aggressive nature of this tumor. However, many recent 
studies have shown good results in limb salvage operations compared to amputation $(7,8)$. The prognosis for patients with localized osteosarcoma has improved considerably with the use of improved surgical techniques for the treatment of the primary site of disease, and the development of effective chemotherapy regimens for the treatment regimens $(3,9)$.

The purpose of the limb salvage surgery is resection of the local tumor and maintain the normal soft tissue as much as possible, so as to provide a well functioning, tumor-free and painless limb (2).

In the United States, osteosarcoma is the most common primary bone malignancy in children, representing approximately $56 \%$ of malignant bone tumors (5). Although we don't have any data about indicating the annual incidence of osteosarcoma in Turkey, the published data of localized hospital shows that osteosarcoma is the most common malignant bone tumors $(10,11)$.

Retrospective analysis of patients with osteosarcoma in the orthopedics and traumatology clinic of our hospital was aimed in this study.

\section{METHODS}

The data obtained from the archive system data, file information and polyclinic examination notes of the patients who were diagnosed with osteosarcoma in the Orthopedics and Traumatology Clinic of Our Hospital were analyzed retrospectively. All data were evaluated retrospectively.

All lesions were confirmed clinically, radiologically and histopathologically as osteosarcoma. Gender, age, tumor location, direction, tumor size, tumor grade, Enneking stage and treatments were recorded for each patient.

The patient ages were grouped as decades. The administration symptoms of patients were mass, pain, mass-related bleeding and the combination of these findings.

Patient management types were divided into operative (limbsparing surgery or amputation), and non-operative (inoperable or patients who did not accept surgical treatment). A hundred and seventeen patients (95.9\%) were operated. Limb-sparing surgery was performed in 85 patients (72.7\%) of these patients and amputation / disarticulation was performed in 32 patients $(26.2 \%)$.

\section{Statistical Analysis}

All statistical analyses were performed using IBM SPSS 22.0 statistical software (IBM Corp., Armonk, NY, USA). Descriptive statistics are expressed as mean \pm standard deviation, frequency, and percentage.

\section{RESULTS}

Between January 2002 and January 2015, 122 consecutive patients with osteosarcoma were included in this study.

Eighty-one (\%66) of the 122 patients were male and 41 (\%34) were female. The average age of the patients was 23.9 (range 7 to 82 years). The mean follow-up period was 49.3 months (range 1-164 months).

The lesion was most commonly located in the knee (81 patients, 66.3\%). Distal femur in 62 patients(50.8\%), proximal tibia in 19 patients $(15.5 \%)$, proximal humerus in $11(9.0 \%)$, proximal fibula in 11 patients $(9.0 \%$ ), pelvis in 6 , extraskeletal in 4, proximal femur in 3 , femur shaft in 3 , humerus diaphysis in 1, distal radius in 1 and scapula in 1 were seen. Sixty-two of the lesions were located on the right $(50.8 \%)$ and sixty of the lesions $(49,2 \%)$ were on the left side.

The mean tumor size was $15.6 \mathrm{~cm}$ (3-61 cm). According to the results of histopathological examination, 79 patients were high grade, 6 patients were low grade and 37 patients were not graded. The patients were evaluated according to Enneking surgical staging system. At the time of diagnosis, $72(59.0 \%)$ patients were stage $2 \mathrm{~B}$ and $44(36 \%)$ patients were stage 3B.

Sixty-one patients $(50 \%)$ were the relative young patient group (11-20 years old) with a mean age of 15.5 years. This age range was followed by 21-30 age group (19 patients, 15,5\%).

Adress for correspondence: Uzm. Dr. recep öztürk Dr. Abdurrahman Yurtaslan Ankara Onkoloji Eğit. ve Araş. Hastanesi Mehmet Akif Ersoy Mahallesi 13. Cadde No: 56 Yenimahalle 06200 Ankara - Türkiye

e-mail: ozturk_recep@windowslive.com

Available at www.actaoncologicaturcica.com

Copyright $\odot$ Ankara Onkoloji Hastanesi 


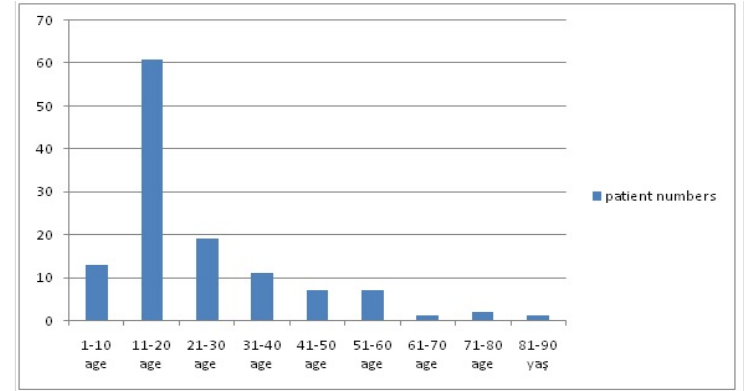

Figure 1. Shows the distribution of patients by age groups

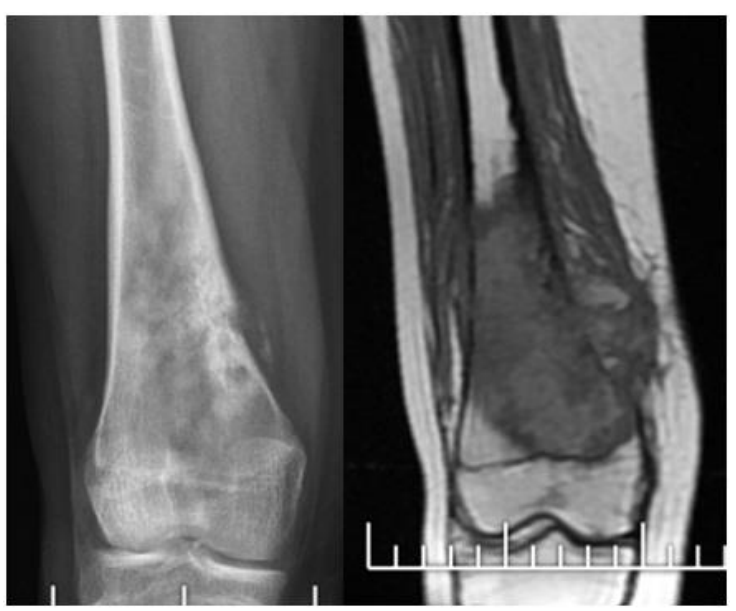

Figure 2. 14-year-old female patient, right distal femurosteosarcoma. The patient's direct X-ray and MRI images show a mass in the right femur distal diaphysis and metaphyseal part extending in the medial direction to the epiphysis and in the coronal plane at the widest part of the mass, measuring $117 \times 87$ $\mathrm{mm}$.

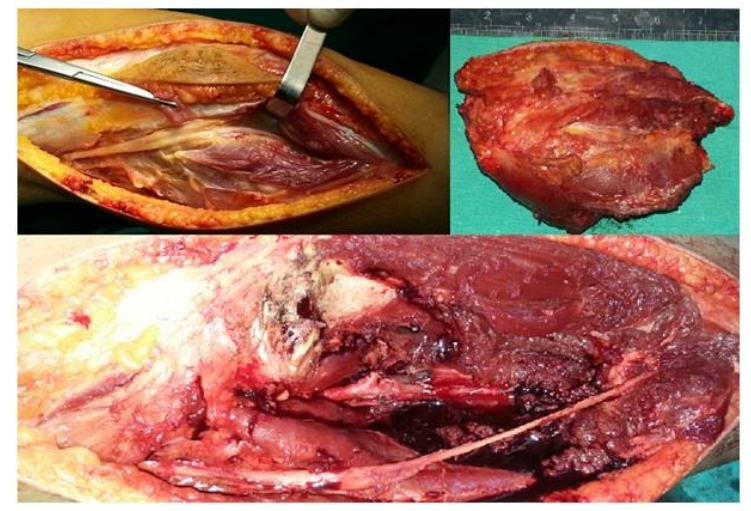

Figure 3. Proximal fibula osteosarcoma, intraoperative images, a) biopsy tract must be removed, if resection can be performed by preserving the local neurovascular structures. b) resected tumoral mass c) tumor site after resection, tibial and peroneal neurovascular structures preserved

\section{DISCUSSION}

Osteosarcoma is the most common seen primary bone tumor. It is including $20 \%$ of primary malignant bone tumors (2).

In the past, patients with osteosarcoma have undergone only amputation treatment, $85 \%-90 \%$ of whom had recurrence in the first 12 months. Adjuvant and neoadjuvant chemotherapy have been improved the prognosis in the last 25 years $(11,12)$. Limb sparing techniques found in the early 1970s. Simon and Ark. and Rougraff et al., have been reported that survival rates are not different in limb salvage or amputation cases but there is a higher local recurrence rate with $\operatorname{limb}$ salvage technique. It is generally accepted that, if the surgery is performed in an appropriate oncological way, it does not impair the duration of life in various techniques $(5,15,16)$.

According to the literature, conventional osteosarcoma is more common in men than in women. The tumor most frequently affects patients who are in the second decade of life and the rate is more than $60 \%$ in patients under 25 years of age. The incidence of osteosarcoma also increases in the 6th decade of life, so there is a bimodal distribution of the disease $(2,5)$. In our study, the highest rate was found in males and the second most common age was the second 10 years of life. However, in the advanced age group, we could not find the second peak in our cases.

In the osteosarcoma, the distal femur and proximal tibia are the most common sites, followed by the proximal humerus, more rarely in the diaphysis of the long bones and, more rarely, in the flat bones. In our study, the most common site was kneefollowed by proximal humerus $(1,2,5,7)$.

The most common symptoms were pain $(90 \%)$, bone swelling $(50 \%)$, limitation of movement (45\%) and pathological fracture $(8 \%)$ are seen. Alkaline phosphatase may be increased $(50 \%)$. It shows increased build-up and destruction in the bone. Other common symptoms include weight loss, fever, and fatigue $(2,5)$. In our study, pain 
and swelling were the most common first symptoms also there were joint dysfunction and pathological fracture or their combinations as the first symptoms .

Clinicians evaluate many bone-related lesions in their daily practice for deformities or benign pathologies. If there is a malignant tumor or osteosarcoma suspicion clinically and radiologically patients should be directed to tertiary care centers where primary therapy can be performed before biopsy. Full body screening and biopsy should be performed at the center where the final treatment will be performed. Because biopsies performed with inappropriate technique can lead to major problems that result in loss of limb or mortality (2,17-19).

We had published retrospectively the data of osteosarcoma cases which were between 1993 and 1996 in our clinic (17). The most frequent age range was 11-20 and the most frequent location of the tumor was around the knee in that retrospective analysis. Limb salvage surgery rate was $68.5 \%$ at that time and it is $72.7 \%$ nowadays.

There is no conflict on the necessity of multidisciplinary approach in all malignant tumors, including osteosarcoma. General treatment principle is preoperative (neoadjuvant) chemotherapy, in some cases (recurrent cases and widespread metastases to be considered inoperable)radiotherapy, if possible, is a postoperative chemotherapy regimen based on the extent of limb sparing surgery and tumor necrosis in classical osteosarcoma. Amputation is performed in patients who cannot undergo limb sparing surgery (2). In our hospital, the follow-up and treatment of patients are performed by a multidisciplinary team consisting of orthopedists, medical oncologists, radiation oncologists, radiologists and pathologists.

\section{REFERENCES}

1. Ando K, Heymann MF, Stresing V, Mori K, Rédini F, Heymann D. Current therapeutic strategies and novel approaches in osteosarcoma. Cancers (Basel). 2013;5(2):591616. doi: 10.3390/cancers5020591.

2. Ozturk R. Kemik ve Yumuşak doku Tümörleri. Atay T, editör. Ortopedi ve Spor Yaralanmaları

Adress for correspondence: Uzm. Dr. recep öztürk Dr. Abdurrahman Yurtaslan Ankara Onkoloji Eğit. ve Araş. Hastanesi Mehmet Akif Ersoy Mahallesi 13. Cadde No: 56 Yenimahalle 06200 Ankara - Türkiye

e-mail: ozturk_recep@windowslive.com

Available at www.actaoncologicaturcica.com

Copyright (Ankara Onkoloji Hastanesi
Asistan Kitab1 (1. Bask1). Ankara Derman T1bbi Yayıncilı; 2015 :635-704. doi: 10.4328/DERMAN.3774.

3. Thompson RC Jr, Cheng EY, Clohisy DR, Perentesis J, Manivel C, Le CT. Results of treatment for metastatic osteosarcoma with neoadjuvant chemotherapy and surgery. Clin Orthop Relat Res. 2002;(397):240-7. doi: 10.1097/00003086-200204000-00028.

4. Atalay İB, Yılmaz S, Korkmaz İ, Ekşioğlu MF, Güngör BŞ. Surgical management of primary malignant proximal fibular tumors: Functional and clinical outcomes of 23 patients. Eklem Hastalik Cerrahisi 2019;30(1):24-31 doi: 10.5606/ehc.2019.62888.

5. Kamal AF, Widyawarman $\mathrm{H}$, Husodo $\mathrm{K}$, Hutagalung EU, Rajabto W.. Clinical Outcome and Survival of Osteosarcoma Patients in Cipto Mangunkusumo Hospital: Limb Salvage Surgery versus Amputation. Acta Med Indones. 2016;48(3):175-183.

6. Atalay İB, Şimşek MA, Irak Ö, Ekşioğlu MF, Güngör BŞ. Biological Reconstruction in Malignant Bone Tumors. Acta Oncol Tur. 2018; 51(3): 283-293. doi: 10.5505/aot.2018.91885.

7. Mankin H, Hornicek F, Rosenberg A, Harmon DC, Gebhardt MC. Survival data for 648 patients with osteosarcoma treated at one institution. Clin Orthop Relat R. 2004:286-91. doi: 10.1097/01.blo.0000145991.65770.e6.

8. Marulanda GA, Henderson ER, Johnson DA, Letson GD, Cheong D. Orthopedic surgery options for the treatment of primary osteosarcoma. Cancer Control. 2008;15(1):13-20. doi: 10.1177/107327480801500103.

9. Bacci G, Ferrari S, Mercuri M, et al. Neoadjuvant chemotherapy for extremity osteosarcoma: Preliminary results of the Rizzoli's 4th study. Acta Oncol. 1998;37(1):4148.

10. R Ozturk, M Aydin, SM Arikan, Şimşek MA, Toptaş E. Extremity Soft Tissue Sarcomas of Uncertain Differentiation: Presentation, Treatment and Outcomes in a Clinical Series of 60 Patients. Bakırköy Tıp Dergisi 2018;14:31-9. doi: 10.5350/BTDMJB.20161217033551.

11. Öztürk R, Arıkan ŞM, Şimşek MA, Özanlağan E, Güngör BŞ. Management of solitary fibrous tumors localized in extremity: case series and a review of the literature. Eklem Hastalik Cerrahisi. $2017 \quad$;28(2):121-7. doi: 10.5606/ehc.2017.52092.

12. Friedman MA, Carter SK. The therapy of osteogenic sarcoma: current status and thoughts for the future. J Surg Oncol 1972; 4:482-510.

13. Marcove RC, Rosen G. En bloc resections for osteogenic sarcoma. Cancer 1980;45:3040.

14. Briccoli A1, Rocca M, Salone M, Guzzardella GA, Balladelli A, Bacci G. High grade osteosarcoma of the extremities metastatic to the lung: long-term results in 323 patients treated combining surgery and chemotherapy, 1985-2005. Surgical Oncology. 2010;19(4):193199. doi: 10.1016/j.suronc.2009.05.002. 
15. Simon MA, Aschliman MA, Thomas N, Mankin HJ. Limb-salvage treatment versus amputation for osteosarcoma of the distal end of the femur. J Bone Joint Surg Am. 1986;68(9):1331-1337.

16. Rougraff BT, Simon MA, Kneisl JS, Greenberg DB, Mankin HJ. Limb salvage compared with amputation for osteosarcoma of the distal end of the femur. A long-term oncological, functional, and quality-of-life study. J Bone Joint Surg Am. 1994;76(5):649-56. doi: 10.2106/00004623-199405000-00004

17. Arıkan M, Metin E, Güngör BŞ, Karakoç $Y$, Gürler D, İnce B. Osteosarkomda Cerrahi Tedavi
Sonuçlarımız. Acta oncol Turc. 2007; 40(1):2326.

18. Ozturk R, Arıkan ŞM, Bulut EK, Kekeç AF, Güngör BŞ. Distribution and evaluation of bone and soft tissue tumors operated in a tertiary care center. Acta ort tra turc. 2019;53:189-194. doi: 10.3944/AOTT.2014.3013

19. Bayrak A, Kürklü GB, Yargic MP, Tuncer I. Comparison of Tibial Torsion Angles Between Elite Athletes and Sedentary People. Turkish Journal of Sport and Exercise. 2018;20(3):137139. doi: $10.15314 /$ tsed.496317. 